\title{
Nursing taxonomies in hospital discharge planning: a quasi-experimental study
}

\author{
Taxonomias de enfermagem no planejamento de alta hospitalar: estudo quase experimental \\ Taxonomías de enfermería en la planificación del alta hospitalaria: investigación cuasi experimental
}

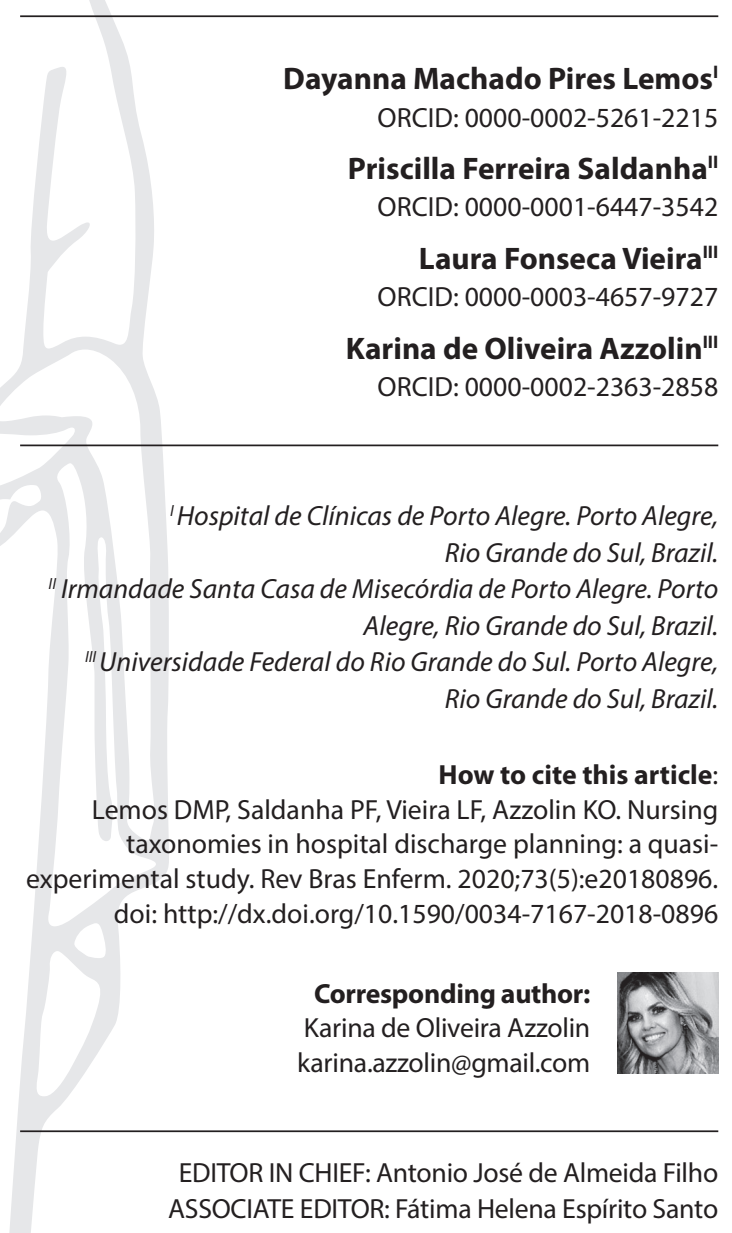

Submission: 11-16-2018

Approval: 10-18-2019

\begin{abstract}
Objective: to evaluate the effect of implementation of hospital discharge planning based on the taxonomies of NANDA-International, nursing interventions classification (NIC) and nursing outcomes classification (NOC) for patients with heart failure (HF) or diabetes mellitus (DM). Methods: quasi-experimental quantitative study conducted in a public university hospital located in the state of Rio Grande do Sul, Brazil. Convenience sampling included 28 adult patients hospitalized for HF or DM with the nursing diagnosis Ineffective Health Management (00078), who received the following nursing interventions: Teaching: Disease Process, Teaching: Prescribed Medication and Teaching: Prescribed Diet. Before and after the intervention, the following nursing outcomes were evaluated: Knowledge: Diabetes Management and Knowledge: Heart Failure Management. Results: the score of the nursing outcome Knowledge: Heart Failure Management went from $2.05 \pm 0.28$ to $2.54 \pm 0.30(\mathrm{P}=0.002)$, and of the nursing outcome Knowledge: Diabetes Management went from $2.61 \pm 0.55$ to $3.21 \pm 0.57(P=0.000)$. Conclusion: discharge planning based on the NIC improves the NOC score and may interfere in the health outcomes.

Descriptors: Nursing; Patient Discharge; Nursing Process/Classification; Heart Failure; Diabetes Mellitus.
\end{abstract}

\section{RESUMO}

Objetivo: avaliar o efeito de um planejamento de alta baseado nas taxonomias NANDA-I, Classificação das intervenções de enfermagem (NIC) e Classificação dos resultados de enfermagem (NOC), implementado para pacientes com insuficiência cardíaca (IC) ou diabetes mellitus (DM). Método: Estudo quantitativo quase-experimental realizado em hospital público e universitário do Sul do Brasil. Amostragem por conveniência com 28 pacientes internados por IC ou DM com Diagnóstico de enfermagem Controle ineficaz da saúde, que receberam as intervenções Ensino: processo de doença, Ensino: medicação prescrita e Ensino: dieta prescrita. Antes e após, foram avaliados os Resultados Conhecimento: controle do diabetes e Conhecimento: controle da insuficiência cardíaca congestiva. Resultados: O NOC Conhecimento: controle da insuficiência cardíaca congestiva passou de $2,05 \pm 0,28$ a 2,54 $\pm 0,30(P=0,002)$ e o Resultado Conhecimento: controle do diabetes passou de $2,61 \pm 0,55$ a 3,21 $\pm 0,57(\mathrm{P}=0,000)$. Conclusão: O planejamento de alta utilizando as intervenções NIC melhora a pontuação dos resultados NOC e pode interferir nos desfechos de saúde.

Descritores: Enfermagem; Alta do Paciente; Processo de Enfermagem/Classificação; Insuficiência Cardíaca; Diabetes Mellitus.

\section{RESUMEN}

Objetivo: evaluar el efecto de la implementación de un plan de alta hospitalaria basado en la taxonomía de NANDA-Internacional, clasificación de intervenciones de enfermería (NIC) y clasificación de resultados de enfermería (NOC), para pacientes con insuficiencia cardíaca (IC) o diabetes mellitus (DM). Métodos: estudio cuantitativo cuasi experimental realizado en un hospital universitario público ubicado en el estado de Rio Grande do Sul, Brasil. El muestreo de conveniencia incluyó a 28 pacientes adultos hospitalizados por IC o DM con el diagnóstico de enfermería Gestión de Salud Inefectiva (00078), que recibieron las siguientes intervenciones de enfermería: Enseñanza: Proceso de la enfermedad, Enseñanza: Medicación prescrita y Enseñanza: Dieta prescrita. Antes y después de la intervención, se evaluaron los siguientes resultados de enfermería: Conocimiento: Control de la diabetes y Conocimiento: Control de la insuficiencia cardíaca congestiva. Resultados: la puntuación del resultado de enfermería Conocimiento: Control de la insuficiencia cardíaca congestiva pasó de $2.05 \pm 0.28$ a $2.54 \pm 0.30(P=0.002)$, y del resultado de enfermería Conocimiento: Control de la diabetes pasó de $2.61 \pm 0.55$ a $3.21 \pm 0.57(P=0,000)$. Conclusión: la planificación de alta basada en la NIC mejora la puntuación de NOC y puede interferir en los resultados de salud.

Descriptores: Enfermería; Alta del Paciente; Proceso de Enfermería/Clasificación; Insuficiencia Cardíaca; Diabetes Mellitus. 


\section{INTRODUCTION}

Safe clinical practice and efficient nursing research and education are based on the use of a homogeneous language. The NANDA-I Nursing Diagnoses Classification ${ }^{(1)}$, Nursing Outcomes Classification (NOC) ${ }^{(2)}$, and Nursing Interventions Classification $(\mathrm{NIC})^{(3)}$ are among the most studied classification systems currently. They can be used with several theoretical references in the most different domains and environments of nursing practice ${ }^{(4)}$. The linkage of these taxonomies enables the identification, understanding and/or prediction of individual human needs by offering subsidy to select those requiring intervention of nursing professionals ${ }^{(4)}$.

Discharge planning is an important part of nursing care and should begin early for better outcomes ${ }^{(5-6)}$. It is the beginning of the transition process between inpatient hospital care and care provided to patients in other health contexts, and a strategy to prepare both patients and their families for taking over the responsibility for the continuity of care safely and effectively ${ }^{(7)}$.

In previous studies, during the clinical evaluation of patients with decompensated Heart Failure (HF) and Diabetes Mellitus (DM), has been identified the nursing diagnosis (ND) of the NANDA-I Health Promotion domain more specifically related to self-care, lack of knowledge about the disease and treatment, and noncompliance with prescribed care ${ }^{(8-9)}$. In Brazil, are recorded more than 20,000 deaths from $\mathrm{HF}$ and 5,000 deaths from DM and their complications per year, which represents mortality rates around 10.4 and 4.5, respectively. In addition, hospital admissions for these reasons generate health care costs of over R\$380 million $^{(7)}$.

Difficulties with pharmacological treatment and nonpharmacological care may be modifiable factors if adequately addressed by the health team. Educational nursing interventions performed in the hospitalization period improve patients' knowledge ${ }^{(10)}$ and self-care, and these can be evaluated through NOC results ${ }^{(11)}$.

Nurses play a fundamental role in this process by acting in its planning, implementation and coordination ${ }^{(12)}$. However, nursing professionals should implement the systematization of care for hospital discharge. Studies testing effective strategies of discharge planning are still scarce and do not address the nursing process as a method, nor the use of nursing classifications.

\section{OBJECTIVE-}

To evaluate the effect of the implementation of hospital discharge planning based on NANDA-I, NOC and NIC taxonomies for patients with HF or DM.

\section{METHODS}

\section{Ethical aspects}

The guidelines and norms regulating research on human beings of resolution 466/2012 of the Brazilian National Health Council were respected. The project was approved by the Research Ethics Committee of the study institution (\#13-0194).

\section{Design, place of study and period}

A quantitative quasi-experimental study. It was conducted between January 2014 and September 2015 in emergency and inpatient units of a public university hospital accredited by the Joint Commission International and located in the state of Rio Grande do Sul. Patients of the emergency unit were included because of their long length of stay, including those staying longer than six days and discharged from this sector. This is a frequent scenario both in the study institution and in other emergency departments of the Unified Health System (Brazilian SUS).

\section{Population and sample}

Convenience sampling included patients who have had HF or DM for at least a year and were hospitalized because of one of these decompensated diseases. They should also have had at least a previous hospitalization for that reason, during which they should have presented the defining characteristics of the ND Ineffective Health Management (IHM) - 00078. Patients residing in long-term institutions or who had a professional caregiver were excluded from the study, in addition to those with terminal illnesses, surgery planned for the same hospitalization period, discharge in up to 48 hours or without clinical and cognitive conditions to answer the questions.

A pilot study was conducted with the first ten patients to observe the variation of NOC indicators. The sample calculation was estimated for the result of improved NOC score, which considered the one-point difference between the two evaluations of NOC results. The WinPepi program version 11.43 was used. For $90 \%$ power, and alpha error of $1 \%$, it is necessary to include ten patients per study subgroup (HF or DM).

\section{Study protocol}

The researcher evaluated and identified the ND Ineffective Health Management when there were at least two of its defining characteristics. This ND was validated by participants because they were all questioned about the agreement or disagreement with it. Researchers were previously trained and had clinical experience with the use of nursing diagnoses. Then, each patient's knowledge on the disease and treatment was evaluated through the NOC Knowledge: Heart Failure Management (1835) in patients admitted for HF, or through the NOC Knowledge: Diabetes Management (1820) in patients hospitalized for DM. This evaluation was denominated baseline NOC. Subsequently, the nursing interventions Teaching: Disease Process (5602), Teaching: Prescribed Medication (5616) and Teaching: Prescribed Diet (5614) were implemented at three different times throughout the hospitalization period. Interventions were performed in face-to-face meetings lasting 20 to 40 minutes with verbal orientation. The individualization of interventions for each pathology was developed by consulting the guidelines ${ }^{(13-14)}$. After the educational intervention and before hospital discharge, the knowledge of each patient was reassessed through the same nursing outcome applied in the first visit. This evaluation was called final NOC. 
Each NOC indicator was operationally defined by the researchers and evaluated through a five-point Likert scale ${ }^{(2)}$. The NOC mean value was obtained with the Likert scale score of each indicator. Subsequently, was calculated the sum of scores of indicators, and were established the statistical means at the two moments. For patients with the two pathologies under study (HF and DM), the discharge planning addressed both, but the evaluation of NOC results was performed only for the reason of the current hospitalization. The effectiveness of interventions was verified by comparing the mean values of baseline NOC and final NOC.

During the development of this study, there were changes in NANDA-I and NOC taxonomies because new editions were released. In the earlier version of NANDA-I, the ND previously titled Ineffective Health Self-Control, was changed to Ineffective Health Management ${ }^{(1)}$, and the fifth defining characteristic: "Expression of desire to control the disease" was suppressed. Furthermore, the nursing outcome Knowledge: Heart Failure Management, previously called Knowledge: Congestive Heart Failure Management, was reviewed in the NOC 5 th edition ${ }^{(2)}$, from which five indicators were excluded (183506, 183510, 183518, 183520 and 183522). Both titles were updated, but the deleted content was maintained because of the study progress.

\section{Analysis of results and statistical}

The Statistical Package for the Social Sciences (SPPS) version 18.0 was used for data analysis. The continuous variables were described as mean and standard deviation or median and interquartile ranges. The Kolmogorov-Smirnov test was applied for definition of normality. Categorical variables were described with absolute and relative frequencies. The comparison between the mean values of results and NOC indicators of the two moments was analysed by the Wilcoxon test. The Pearson's correlation coefficient was used to evaluate the linear association between the NOC results and sociodemographic data, clinical, and about medication in use. A two-tailed $\mathrm{P} \leq 0.05$ was considered statistically significant.

\section{RESULTS}

Thirty-three patients were included, of whom four were discharged from hospital and one died before the end of the study. Thus, 28 patients (14 hospitalized for HF and 14 for DM) received a total of 84 interventions. Patients were predominantly male (53.6\%), mean age of 55 years. Sociodemographic and clinical data are shown in Table 1.

The ND was validated by 25 patients (89.3\%), 13 hospitalized for HF and 12 for DM, who agreed with the proposed diagnosis. Three other patients did not agree with the proposed diagnosis, but they presented at least four out of the five defining characteristics that compose the ND, and all accepted to receive the interventions hence, they remained in the study.

Twenty-one participants (75\%) presented four out of the five defining characteristics of the ND Ineffective Health Management. Of these, Health-Seeking Behaviour prevailed in 27 participants (96.4\%). Although in the 2018-2020 edition of the NANDA-I nursing diagnoses, the ND Ineffective Health Management no longer contained this defining characteristic, all study subjects had at least one more characteristic of this ND (the new edition was launched while the study was in progress).

The evaluation of baseline NOC was performed in a median of 4 (1.0-6.0) days after admission. The evaluation of the final NOC was performed in up to $3(0.25-7.75)$ days before hospital discharge. In the first evaluation, both cardiac and diabetic patients had a baseline mean score considered limited in the Likert scale. Both results showed significant improvement after the interventions.

In 22 out of the 37 indicators of the outcome Knowledge: Heart Failure Management applied, there was significant difference after three nursing interventions (Table 2).

Of the evaluated indicators, only Medication Therapeutic Effects (183527) had an inverse and strong correlation with the number of drugs used by the patient, $r=-0.66(P=0.009)$, and Medication Side Effects (183528) had a moderate correlation, $r=-0.49(P=0.07)$. In other words, patients using a higher number of medications had lower scores in these indicators.

The mean score of the outcome Knowledge: diabetes management also increased after the intervention. In 17 out of the 30 evaluated indicators, there was a significant difference before and after the three nursing interventions (Table 3).

Table 1 - Sociodemographic and clinical data of patients with heart failure and diabetes mellitus, Porto Alegre, Brazil, 2014-2015

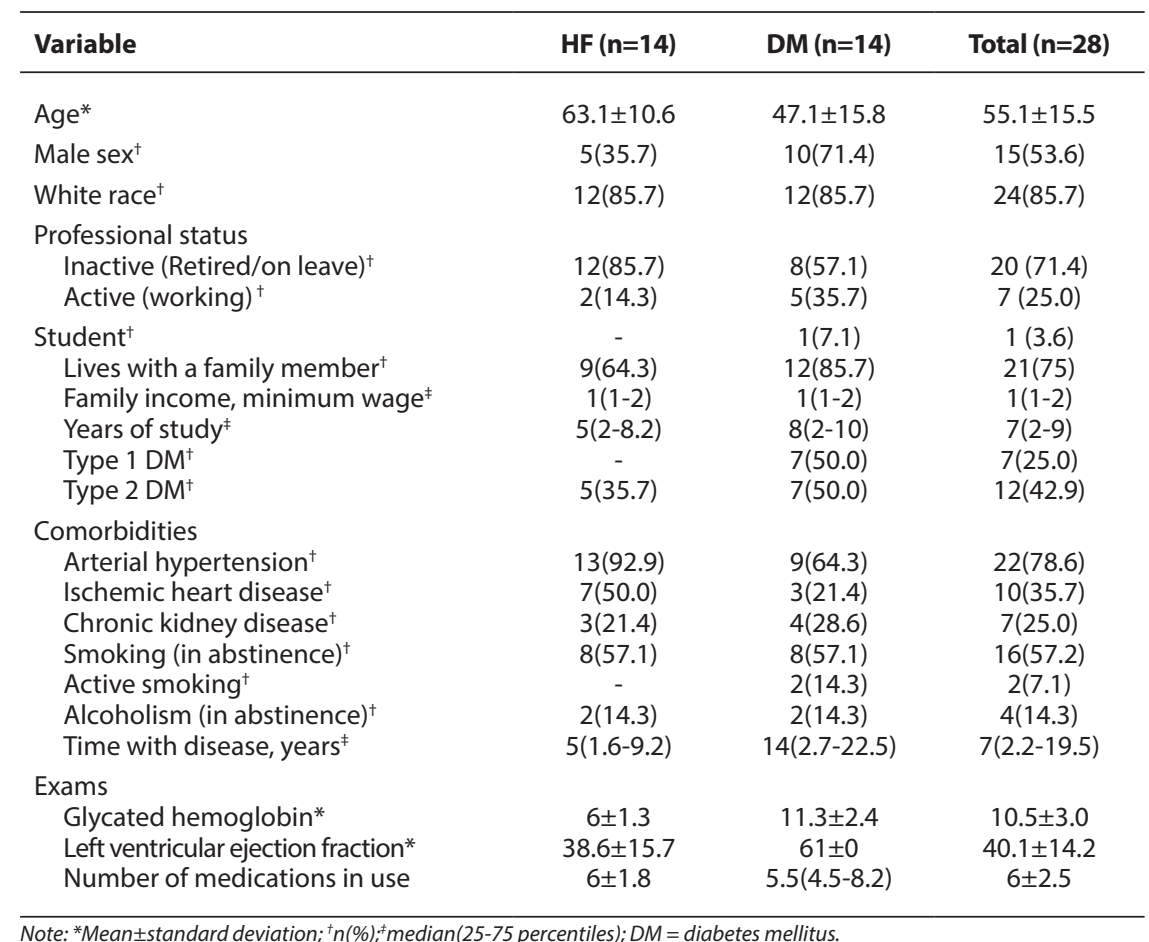


Table 2 - Mean values of nursing outcome indicators Knowledge: Heart Failure Management with significant differences, Porto Alegre, Brazil, 2014-2015

\begin{tabular}{|c|c|c|c|c|}
\hline NOC result/ Indicators & $1^{\text {st }}$ Evaluation & $2^{\text {nd }}$ Evaluation & Mean difference & $p$ value \\
\hline Knowledge: Heart Failure Management (1835) & $2,05 \pm 0,28$ & $2,54 \pm 0,30$ & $0,48 \pm 0,21$ & 0,002 \\
\hline Strategies to balance activity and rest (183519) & $2,36 \pm 1,27$ & $3,57 \pm 1,22$ & 1,21 & 0,002 \\
\hline Strategies to manage edema (183523) & $1,57 \pm 0,75$ & $2,64 \pm 0,92$ & 1,07 & 0,004 \\
\hline Basic actions of the heart (183504) & $2,43 \pm 0,85$ & $3,43 \pm 1,01$ & 1,00 & 0,002 \\
\hline Signs and symptoms of overexertion (183511) & $2,57 \pm 1,01$ & $3,50 \pm 0,94$ & 0,93 & 0,006 \\
\hline Importance of rest for disease management (183518) & $2,21 \pm 1,12$ & $3,14 \pm 1,02$ & 0,93 & 0,010 \\
\hline Cause and contributing factors (183501) & $1,50 \pm 0,76$ & $2,36 \pm 1,00$ & 0,86 & 0,006 \\
\hline Pattern and type of edema (183522) & $2,00 \pm 0,87$ & $2,86 \pm 0,86$ & 0,86 & 0,010 \\
\hline Factors contributing to weight changes (183524) & $1,57 \pm 0,64$ & $2,43 \pm 0,51$ & 0,86 & 0,001 \\
\hline Signs and symptoms of progressive heart failure (183505) & $2,29 \pm 0,61$ & $3,14 \pm 0,86$ & 0,85 & 0,008 \\
\hline Benefits of disease management (183503) & $2,07 \pm 0,99$ & $2,86 \pm 0,86$ & 0,79 & 0,005 \\
\hline Strategies to prevent respiratory distress (183520) & $2,57 \pm 1,22$ & $3,29 \pm 0,91$ & 0,72 & 0,026 \\
\hline Strategies to manage weight (183525) & $1,36 \pm 1,08$ & $2,07 \pm 0,99$ & 0,71 & 0,004 \\
\hline Signs and symptoms of early disease (183502) & $2,14 \pm 0,77$ & $2,79 \pm 0,89$ & 0,65 & 0,014 \\
\hline Medications therapeutic effects (183527) & $1,57 \pm 0,85$ & $2,21 \pm 0,97$ & 0,64 & 0,014 \\
\hline Strategies to control anxiety (183515) & $1,43 \pm 0,51$ & $2,00 \pm 0,78$ & 0,57 & 0,011 \\
\hline Strategies to increase diet compliance (183526) & $2,57 \pm 1,01$ & $3,14 \pm 0,94$ & 0,57 & 0,046 \\
\hline When to obtain assistance from health professional (183537) & $2,86 \pm 1,02$ & $3,43 \pm 0,85$ & 0,57 & 0,023 \\
\hline Signs and symptoms of tachycardia (183510) & $1,93 \pm 0,61$ & $2,43 \pm 0,85$ & 0,50 & 0,020 \\
\hline Self-monitoring techniques (183531) & $2,07 \pm 1,07$ & $2,57 \pm 1,01$ & 0,50 & 0,035 \\
\hline Strategies to promote peripheral circulation (183517)\| & $1,29 \pm 0,46$ & $1,71 \pm 0,61$ & 0,42 & 0,034 \\
\hline Treatments to improve cardiac performance (183516)\| & $1,57 \pm 0,64$ & $1,86 \pm 0,77$ & 0,29 & 0,046 \\
\hline Signs and symptoms of orthostatic hypotension (183506)‡ & $1,43 \pm 0,51$ & $1,71 \pm 0,46$ & 0,28 & 0,046 \\
\hline
\end{tabular}

Note: * Data presented as mean \pm standard deviation. $P=$ mean difference (Wilcoxon). $1^{\text {st }}$ evaluation performed in the inclusion of patients in the study. $2^{\text {nd }}$ evaluation performed after three interventions.

Table 3 - Mean nursing outcome indicators Knowledge: diabetes management with significant differences. Porto Alegre, 2014-2015

\begin{tabular}{|c|c|c|c|c|}
\hline NOC result/ Indicators & $1^{\text {st }}$ Evaluation & $2^{\text {nd }}$ Evaluation & Mean difference & $p$ value \\
\hline Knowledge: Diabetes Management (1820) & $2,61 \pm 0,55$ & $3,21 \pm 0,57$ & $0,59 \pm 0,20$ & 0,000 \\
\hline Impact of acute illness on blood glucose level $(182013)^{\dagger}$ & $2,79 \pm 1,31$ & $4,14 \pm 0,77$ & 1,35 & 0,003 \\
\hline Proper disposal of syringes and needles $(182035)^{\S}$ & $2,36 \pm 1,56$ & $3,64 \pm 1,43$ & 1,28 & 0,016 \\
\hline Preventive foot care practices (182023) \| & $2,43 \pm 1,01$ & $3,50 \pm 0,94$ & 1,07 & 0,027 \\
\hline Plan to rotation of injection sites $(182018)^{\S}$ & $3,18 \pm 0,87$ & $4,09 \pm 0,53$ & 0,91 & 0,015 \\
\hline Prescribed meal plan (182003)" & $2,21 \pm 0,80$ & $3,00 \pm 0,87$ & 0,79 & 0,015 \\
\hline Procedures to be followed in treating hypoglycemia (182011)\| & $2,14 \pm 0,94$ & $2,93 \pm 0,91$ & 0,79 & 0,009 \\
\hline Actions to take in response to blood glucose levels $(182015)^{+}$ & $2,00 \pm 0,78$ & $2,79 \pm 0,80$ & 0,79 & 0,001 \\
\hline Hyperglycemia and related symptoms $(182006)^{\dagger}$ & $2,36 \pm 1,15$ & $3,14 \pm 1,02$ & 0,78 & 0,009 \\
\hline Medication therapeutic effects $(182039)^{\S}$ & $2,86 \pm 1,61$ & $3,64 \pm 1,27$ & 0,78 & 0,014 \\
\hline Role of diet in blood glucose control (182002)" & $2,64 \pm 0,74$ & $3,36 \pm 0,63$ & 0,72 & 0,008 \\
\hline How to use a monitoring device $(182033)^{\ddagger}$ & $2,21 \pm 1,47$ & $2,93 \pm 1,38$ & 0,72 & 0,008 \\
\hline Strategies to increase diet compliance (182004) & $2,64 \pm 0,74$ & $3,29 \pm 0,61$ & 0,65 & 0,007 \\
\hline Signs and symptoms of early disease $(182031)^{\dagger}$ & $2,00 \pm 1,10$ & $2,64 \pm 1,08$ & 0,64 & 0,014 \\
\hline Hyperglycemia prevention (182007)\| & $2,71 \pm 0,91$ & $3,21 \pm 0,57$ & 0,50 & 0,038 \\
\hline Prescribed oral medication regimen $(182020)^{\varsigma}$ & $2,29 \pm 1,32$ & $2,79 \pm 1,31$ & 0,50 & 0,038 \\
\hline When to obtain assistance from a health professional $(182042)^{\ddagger}$ & $3,21 \pm 1,12$ & $3,71 \pm 1,06$ & 0,50 & 0,008 \\
\hline Proper technique to draw up and administer insulin $(182027)^{\S}$ & $3,36 \pm 1,02$ & $3,82 \pm 1,25$ & 0,46 & 0,025 \\
\hline Benefits of disease management $(182024)^{\dagger}$ & $2,86 \pm 1,02$ & $3,29 \pm 1,20$ & 0,43 & 0,034 \\
\hline
\end{tabular}


Among the indicators, Medication Therapeutic Effects also showed strong inverse correlation, $r=-0.68(p=0.007)$, with the number of drugs used by patients. Similarly, the indicators Prescribed Insulin Regimen and Correct Use of Prescribed Medication showed inverse and moderate correlation, $r=-0.50(p=0.114)$ and $r=-0.40(p=0.148)$, with the number of drugs.

\section{DISCUSSION}

This study revealed that the nursing education interventions included in a hospital discharge plan improved the results of knowledge about disease and treatment in patients with HF and DM who presented the ND Ineffective Health Management.

The applicability of these interventions in patients with DM and HF has been studied previously. In the literature, the interventions Teaching:Prescribed Medication and Teaching:Disease Process have been selected by a consensus of specialists for implementation in patients with $\mathrm{HF}$ in the home environment ${ }^{(15)}$ and identified in intrahospital clinical practice together with the intervention Teaching: Prescribed Diet ${ }^{(8)}$. These are also considered as main interventions because of the NOC and NIC linkages for clinical conditions related to the outcome Knowledge: diabetes management $t^{(4,16-17)}$.

The outcome Knowledge: Heart Failure Management showed significant mean difference but remained as limited knowledge in this study. This result obtained a significant increase in 22 indicators. Of these, nine addressed nonpharmacological treatment, seven the self-monitoring of disease, four the knowledge of disease, only one addressed medication and another one the psychosocial area. When the mean value of the same result was evaluated in another study with patients hospitalized for decompensated HF, it went from limited $(2.73 \pm 1.09)$ to moderate $(3.55 \pm 0.88)$ after seven days of follow-up ${ }^{(18)}$. Similar results were obtained in the evaluation of treatment adherence at home using a validated questionnaire, where $53.1 \%$ of patients reached the minimum score of 18 points in the first evaluation, and $81.3 \%$ of them achieved that same score $(P=0.001)$ after three nursing interventions ${ }^{(19)}$. The application of the same instrument to assess treatment adherence in patients with HF in outpatient follow-up identified that only $36.5 \%$ of them presented a satisfactory adherence rate $(\geq 70 \%)^{(20)}$.

Still in a home setting, the knowledge of patients with HF had a significant increase in nursing outcome scores after four interventions. The mean value of the outcome Knowledge:Medication went from $2.28 \pm 0.14$ to $3.55 \pm 0.16(\mathrm{P}<0.001)$ and Knowledge: Treatment Regimen went from $2.33 \pm 0.14$ to $3.59 \pm 0.14(\mathrm{P}<0.001)^{(19)}$. Of the four indicators that address pharmacological treatment, only Medication Therapeutic Effects had a significant score increase after three interventions. These results are relevant given the evidence that lack of adherence to pharmacological treatment is primarily related to adverse drug effects ${ }^{(21)}$. However, polypharmacy, frequent doses, cost of therapy, lack of access to medication because of low-income, unwanted effects of medications, depression and lack of guidance on the importance of this treatment at the time of hospital discharge were also mentioned as contributing factors to poor adherence ${ }^{(21)}$.

Of the indicators evaluated, only Medication Therapeutic Effects and Medication Side Effects showed a strong and moderate inverse correlation, respectively, with the number of medications used by the patient. This means that patients who used a higher number of medications had worse scores on these indicators. Pharmacological treatment is directly linked to the health outcomes of this population $^{(11)}$. Knowledge about nonpharmacological treatment is more widespread among patients hence, greater commitment is required from health professionals (including nurses) when it comes to medication. Four of the interventions implemented in our study were focused on nonpharmacological treatment.

Out of the 15 indicators of the outcome Knowledge: Heart Failure Management without significant difference between the mean scores of the first and second evaluation, eight indicators were of psychosocial nature.

Coping with the disease may reflect on the perception of $\mathrm{HF}$ patients about their current state of health in the medium and long term. Up to $60 \%$ of HF patients reported being slightly worse at the current moment (present time) compared to a year before in relation to their disease ${ }^{(22)}$. These patients also have a worse perception of health compared with the general population ${ }^{(23)}$, and higher incidence of depressive traits ${ }^{(24)}$. Regarding sexual activity, the indicators Effects on Sexuality and Adaptations for Sexual Performance presented low mean values and small difference between the two evaluations. Sexual dysfunction is known to be a recurrent problem in HF patients, and is present in up to $87 \%$ of men and $76 \%$ of women ${ }^{(25)}$.

In the sample of DM patients, the outcome Knowledge: Diabetes Management showed a mean difference $(P=0.000)$ and went from limited knowledge to moderate knowledge in 20 out of the 31 indicators evaluated. Among these indicators, six addressed knowledge about the disease, six were related to medication, three to nonpharmacological treatment, three were about diet and two about self-monitoring of the disease.

After the intervention, the average scores of indicators Impact of Acute IIIness on Blood Glucose Level, Proper Disposal of Syringes and Needles, and Preventive Foot Care Practices increased more than one point. Regarding needle and syringe disposal, another study identified that $51.4 \%$ of DM patients discarded these materials in common trash and were unaware of the route of trash to the landfill(26).

Regarding DM knowledge, patients who participated in an educational program were re-evaluated after five years and had a percentage of hits higher than $70 \%$ regarding the chronic complications of the disease, foot care, self-monitoring, pathophysiology, treatment of disease and hypoglycemia, which suggests that the information was incorporated by patients during the program ${ }^{(27)}$.

Out of the 11 indicators of the outcome Knowledge: Diabetes Management that did not have a significant increase in mean scores, seven addressed medication prescription, of which three were about insulin use. On the other hand, in a study, the validity and reliability of an instrument to measure treatment adherence was assessed by two different ways, namely with oral antidiabetics and with insulin. The conclusion was that the two modalities showed differences in adherence, and insulin therapy had greater adherence than oral antidiabetics $(5.60 \pm 0.45 \text { vs } 5.39 \pm 0.84 \text {, respectively; } p=0.001)^{(28)}$.

After nine months, in a study developed to facilitate physicianpatient communication, there was improvement in adherence to treatment, ranging from 6 to $20 \%$, but clinical results such as sweets consumption, glycated hemoglobin rate, blood pressure level, lipid control and emergency visits remained unchanged ${ }^{(29)}$. In fact, the scarcity of nutritional guidance in the basic health 
network is one of the possible factors contributing to difficulties with effective adherence to a DM-specific $\operatorname{diet}^{(30)}$.

The outcome Knowledge: Diabetes Management does not have indicators of coping with the disease, effects on the patient and family, and psychosocial indicators. As in the population with DM, these areas deserve attention. There is evidence that adherence to DM pharmacotherapy is related to patients' belief in medicines to improve symptoms and protect against disease complications, and is therefore linked to behavioral issues ${ }^{(31)}$. Furthermore, patients' acceptance of the disease and its complications, especially in case of amputations and loss of visual acuity, and the discrepancy between dietary habits adopted by family members and those prescribed for the diabetic patient are some factors interfering in patient's adherence to treatment ${ }^{(32)}$.

The guidelines for HF and DM recommend addressing the abuse of substances such as tobacco, alcohol or illicit drugs, if applicable ${ }^{(14-15)}$. These issues were addressed as part of the NIC Teaching: Disease Process, although it was not possible to evaluate their effectiveness because both implemented NOC do not include indicators for this purpose.

At the end of this study, was found a lack of discharge planning based on nursing diagnoses that guide long-term care, and these are patients living with the disease for a long time who experience multiple readmissions. In this context, the practice of educational actions aimed at improving knowledge about the disease and self-care can benefit the follow-up of chronic patients.

\section{Study limitations}

The limitation of this study was the absence of a control group. This fact makes it impossible to isolate the effect of routine educational interventions by the care team and the study team.

\section{Contributions to the nursing practice}

The implementation of taxonomies in the guidelines for chronic patients' discharge performed here provides information that may support their use in the clinic and enable the systematized nursing care directed to improve patients' knowledge about their disease and treatment. Care guided by nursing diagnoses linked to interventions and assessed through standardized nursing outcomes fills gaps such as the absence of effective evaluation of discharge plans when these are implemented. In addition, it equips teaching and research and corroborates with the advancement of nursing as a modern profession that seeks to qualify its evidence-based practices.

\section{CONCLUSION}

The study findings suggest that hospital discharge planning during hospitalization for patients with decompensated HF and DM with the ND Ineffective Health Management and use of educational nursing interventions significantly improves nursing outcome scores on knowledge about the disease and treatment. However, its systematic application in practice needs to overcome barriers such as the great number of linking possibilities between the three classifications, and the heterogeneity of domains and classes of each of them. We suggest further research on the implementation and testing of the effectiveness of linking NANDA-I, NOC and NIC for their improvement and use in routine care.

\section{FUNDING}

This study was supported by the Fundo de Incentivo à Pesquisa e Eventos do Hospital de Clínicas de Porto Alegre (FIPE-HCPA), Brazil (\#13-0194) and the Universidade Federal do Rio Grande do Sul.

\section{REFERENCES}

1. NANDA I. Diagnósticos de Enfermagem da NANDA: Definições e classificação 2018-2020. Porto Alegre: Artmed; 2017.

2. Moorhead S, Johnson M, Maas ML, Swanson E. Classificação dos resultados de enfermagem (NOC). 5.ed. Rio de Janeiro: Elsevier; 2016.

3. Bulechek GM, Butcher HK, Dochterman JM. Classificação das intervenções de enfermagem (NIC). 6.ed. Rio de Janeiro: Elsevier; 2016.

4. Johnson M, Moorhead S, Bulechek G, Butcher H, Maas M, Swanson E. Ligações NANDA-NOC-NIC: Condições clínicas, suporte ao raciocínio e assistência de qualidade. $3^{\text {a }}$ ed. Rio de Janeiro: Elsevier; 2012.

5. Suzuki VF, Carmona EV, Lima MHM. Planning the hospital discharge of patients with diabetes: the construction of a proposal. Rev Esc Enferm USP [Internet]. 2011[cited 2015 Dec 12];45(2):527-32. Available from: http://www.scielo.br/pdf/reeusp/v45n2/v45n2a31.pdf

6. Pellet C. Discharge planning: best practice in transitions of care. Br J Community Nurs [Internet]. 2016 [cited 2018 Nov 11];21(11):542-8. Available from: https://doi.org/10.12968/bjcn.2016.21.11.542

7. World Health Organization. Global status report on noncommunicable diseases [Internet]. 2014 [cited 2016 Feb 22]. Available from: http:// apps.who.int/iris/bitstream/10665/148114/1/9789241564854_eng.pdf

8. Park H. Identifying Core NANDA-I Nursing Diagnoses, NIC Interventions, NOC Outcomes, and NNN Linkages for Insuficiência cardíaca. Int J Nurs Knowl. 2014[cited 2015 Dec 09];25(1):30-8. Available from: https://onlinelibrary.wiley.com/doi/abs/10.1111/2047-3095.12010

9. Silva LHA, Carmona EV, Beck ARM, Lima MHM, Araújo EP. Nursing diagnoses of diabetic patient medical charts: a descriptive study. O Braz J Nurs [Internet]. 2013 [cited 2017 Jun 16];12(1):62-72. Available from: http://www.objnursing.uff.br/index.php/nursing/article/view/3894

10. Silva AF, Cavalcanti ACD, Malta M, Arruda CS, Gandin T, Fé A, et al. Adherence of patients with heart failure to pharmacological and nonpharmacological treatment in a teaching hospital. Rev Latino-Am Enfermagem [Internet]. 2015 [cited 2017 Jun 07];23(5):888-94. Available from: http://www.scielo.br/pdf/rgenf/v31n2/04.pdf 
11. Rabelo-Silva ER, Saffi MAL, Aliti GB, Feijó MK, Linch GFC, Sauer JM, et al. Precipitating factors of decompensation of heart failure related to treatment adherence: multicenter study-EMBRACE. Rev Gaúcha Enferm [Internet]. 2018 [cited 2018 Nov 11];39:e20170292. Available from: http://www.scielo.br/pdf/rgenf/v39/en_1983-1447-rgenf-39-e20170292.pdf

12. Nunes ECDA, Menezes Filho NA. Systemization os nursing discharge: an analysis based on Roy. Cogitare Enferm [Internet]. 2016 [cited 2017 May 8];21(2):1-9. Available from: https://revistas.ufpr.br/cogitare/article/view/45875/28548

13. Comitê Coordenador da Diretriz de Insuficiência Cardíaca. Diretriz Brasileira de Insuficiência Cardíaca Crônica e Aguda. Arq Bras Cardiol [Internet]. 2018 [cited 2018 Sep 12];111(3):436-539. Available from: http://publicacoes.cardiol.br/portal/abc/portugues/2018/v11103/pdf/11103021.pdf

14. Oliveira JEP, Montenegro Jr RM, Vencio S (org.) Diretrizes da Sociedade Brasileira de Diabetes 2017-2018 [Internet]. São Paulo: Clannad, 2017[cited 2018 Sep 12]. Available from: https://www.diabetes.org.br/profissionais/images/2017/diretrizes/diretrizes-sbd-2017-2018.pdf

15. Azzolin K, Souza EN, Ruschel KB, Mussi CM, Lucena AF, Rabelo ER. Consensus on nursing diagnoses, interventions and outcomes for home care of patients with heart failure Rev Gaúcha Enferm [Internet]. 2012 [cited 2015 Nov 28];33(4):56-63. Available from: http://www.scielo.br/ pdf/rgenf/v33n4/en_07.pdf

16. Scain SF, Franzen E, Santos LB, Heldt E. Accuracy of nursing interventions for patients with type 2 diabetes mellitus in outpatient consultation. Rev Gaúcha Enferm [Internet]. 2013 [cited 2015 Dec 02];34(2):14-20. Available from: http://www.scielo.br/pdf/rgenf/v34n2/en_v34n2a02.pdf

17. Nogueira LCF, Medeiros ACT, Bittencourt GKGD, Nóbrega MML. Diagnósticos, resultados e intervenções de enfermagem ao idoso diabético: estudo de caso. O Braz J Nurs [Internet]. 2016 [cited 2019 Aug 05];15(2):302-12. Available from: http://www.objnursing.uff.br/index.php/ nursing/article/view/4964

18. Linhares JCC, Orlandin L, Aliti GB, Rabelo-Silva ER. Applicability of nursing outcomes in patients with heart failure and fluid volume excess. Rev Gaúcha Enferm [Internet]. 2016 [cited 2016 Oct 29];37(2):1-8. Available from: http://www.scielo.br/pdf/rgenf/v37n2/en_0102-6933rgenf-1983-144720160261554.pdf

19. Azzolin KO, Lemos DM, Lucena AF, Rabelo-Silva ER. Home-based nursing interventions improve knowledge of disease and management in patients with heart failure. Rev Latino-Am Enfermagem [Internet]. 2015 [cited 2016 Apr 02];23(1):44-50. Available from: http://www.scielo. br/pdf/rlae/v23n1/0104-1169-rlae-23-01-00044.pdf

20. Mantovani VM, Ruschel KB, Souza EN, Mussi C, Rabelo-Silva ER. Treatment adherence in patients with heart failure receiving nurse-assisted home visits. Acta Paul Enferm [Internet]. 2015 [cited 2016 Jan 21];28(1):41-7. Available from: http://www.scielo.br/pdf/ape/v28n1/en_19820194-ape-028-001-0041.pdf

21. Albert NM. Improving Medication Adherence in Chronic Cardiovascular Disease. Crit Care Nurse [Internet]. 2008 [cited 2016 Feb 17];28(5). Available from: http://ccn.aacnjournals.org/content/28/5/54.full.pdf+html

22. Soares DA, Toledo JAS, Santos LF, Lima RMB, Galdeano LE. Quality of life of heart failure patients. Acta Paul Enferm [Internet]. 2008 [cited 2017 May 25];21(2):243-8. Available from: https://www2.unifesp.br/acta/pdf/v21/n2/v21n2a2.pdf

23. Castro JL, Conde LC, Rodríguez VF, Garrido JMF, Ortega RA. Analysis of quality of life using the generic SF-36 questionnaire in patients with heart failure. Rev Calid Asist. 2013;28(6):355-60. doi: 10.1016/j.cali.2013.05.008.

24. Gastelurrutia P, Lupón J, Altimir S, Antonio M, González B, et al. Effect of fragility on quality of life in patients with insuficiência cardíaca. Am J Cardiol [Internet]. 2013 [cited 2016 Dec 02];112(11):1785-9. Available from: https://www.ajconline.org/article/S0002-9149(13)01678-0/pdf

25. Jaarsma T. Sexual function of patients with heart failure: facts and numbers. ESC Heart Fail [Internet]. 2017 [cited 2018 Jan 15];4: 3-7. Available from: https://www.ncbi.nlm.nih.gov/pmc/articles/PMC5292636/pdf/EHF2-4-03.pdf

26. Tapia CEV. Diabetes mellitus e o descarte de seringas e agulhas. Rev Gaúcha Enferm [Internet]. 2009 [cited 2015 Dec 02];30(2):228-34. Available from: https://seer.ufrgs.br/RevistaGauchadeEnfermagem/article/view/11310/6696

27. Chagas IA, Camilo J, Santos MA. Patients'knowledge of diabetes five years after the end of an educational program. Rev Esc Enferm USP [Internet]. 2013 [cited 2016 Feb 17];47(5):1141-6. Available from: http://www.scielo.br/pdf/reeusp/v47n5/pt_0080-6234-reeusp-47-05-1137.pdf

28. Gomes-Villas Boas LC, Lima MLSAP, Pace AE. Adherence to treatment for diabetes mellitus: validation of instruments for oral antidiabetics and insulin. Rev Latino-Am Enferm [Internet]. 2014 [cited 2017 Aug 18];22(1):[8 telas]. Available from: http://www.revistas.usp.br/rlae/ article/view/76064/79778

29. Dixon BE, Alzeer AH, Phillips EOK, Marrero DG. Integration of provider, pharmacy, and patient-reported data to improve medication adherence for type 2 diabetes: a controlled before-after pilot study. JMIR Med Inform [Internet]. 2016 [cited 2017 Jan 15];1(4):1-13. Available from: https://asset.jmir.pub/assets/3ea9880a16c3a68f6c790555af4957c1.pdf

30. Veras VS, Santos MA, Rodrigues FFL, Arrelias CCA, Pedersoli TAM, Zanetti M. Self-care among patients enrolled in a self-monitoring blood glucose program. Rev Gaucha Enferm [Internet]. 2014 [cited 2016 Mar 01];35(4): 42-8. Available from: http://www.scielo.br/pdf/rgenf/ v35n4/pt_1983-1447-rgenf-35-04-00042.pdf

31. Borba AKOT, Marques APO, Ramos VP, Leal MCC, Arruda IKG, Ramos RSPS. Factors associated with elderly diabetic adherence to treatment in primary health care. Cienc Saude Colet [Internet]. 2018 [cited 2018 Nov 02];23(3):953-61. Available from: http://www.scielo.br/pdf/csc/ v23n3/en_1413-8123-csc-23-03-0953.pdf

32. Eid LP, Leopoldino SAD, Oller GASAO, Pompeo DA, Martins MA, Gueroni LPB. Factors related to self-care activities of patients with type 2 diabetes mellitus. Esc Anna Nery [Internet]. 2018 [cited 2018 Nov 11];22(4):e20180046. Available from: http://scielo.br/pdf/ean/v22n4/14148145-ean-22-03-e20180046.pdf 